\title{
KORELASI ANTARA KECERDASAN LINGUISTIK DENGAN KOMPETENSI PENGETAHUAN BAHASA INDONESIA SISWA KELAS V SD GUGUS I GUSTI NGURAH RAI DENPASAR BARAT TAHUN PELAJARAN 2017/2018
}

\author{
Ayu Bintang Christina Dewi ${ }^{1}$, I Wayan Sujana ${ }^{2}$, I Ketut Adnyana Putra ${ }^{3}$ \\ 1,2,3 Jurusan PGSD, Universitas Pendidikan Ganesha, Singaraja, Indonesia

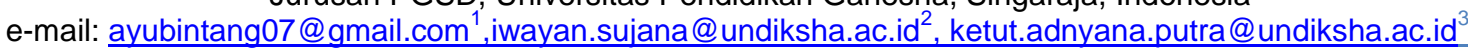

\begin{abstract}
Abstrak
Penelitian ini bertujuan untuk mengetahui korelasi yang signifikan antara kecerdasan linguistik dengan kompetensi pengetahuan bahasa Indonesia siswa kelas V SD Gugus I Gusti Ngurah Rai Denpasar Barat tahun pelajaran 2017/2018. Jenis penelitian ini adalah penelitian ex post facto dengan korelasi yang bersifat asimetris. Populasi dari penelitian ini merupakan siswa kelas V SD Gugus I Gusti Ngurah Rai, Denpasar Barat tahun pelajaran 2017/2018 yang memiliki populasi 533 orang. Penentuan sampel menggunakan teknik proporsional random sampling dengan taraf kesalahan $5 \%$ dan diperoleh banyak sampel dari populasi adalah 218 orang. Data diperoleh dari pencatatan dokumen kompetensi pengetahuan bahasa Indonesia dan tes uraian (essay test) kecerdasan linguistik dari responden. Sebagai uji persyarat adalah uji normalitas sebaran data. Dan berikutnya adalah uji hipotesis menggunakan analisis korelasi product moment. Berdasarkan hasil analisis diperoleh $r_{X y \text { hitung }}=0,448$. Pada taraf kesalahan $5 \%$ dengan $\mathrm{n}=218$, maka diperoleh $r_{X y}$ tabel $=$ 0,138 . Karena $r_{x y}$ hitun $q>r_{x y}$ tabel $=0,448>0,138$ maka dapat diartikan bahwa $H_{0}$ yang berbunyi tidak terdapat korelasi yang siginifikan antara kecerdasan linguistik dengan kompetensi bahasa Indonesia siswa kelas V SD Gugus I Gusti Ngurah Rai Denpasar Barat tahun pelajaran 2017/2018 ditolak dan $H_{a}$ diterima. Jadi dapat disimpulkan bahwa terdapat korelasi yang signifikan antara kecerdasan linguistik dengan kompetensi pengetahuan bahasa Indonesia siswa kelas V SD Gugus I Gusti Ngurah Rai Denpasar Barat tahun pelajaran 2017/2018, dengan arah korelasi positif, artinya semakin tinggi kecerdasan linguistik maka semakin tinggi pula kompetensi pengetahuan bahasa Indonesia yang diperoleh siswa.
\end{abstract}

Kata-kata kunci: kecerdasan linguistik, kompetensi pengetahuan bahasa Indonesia

\begin{abstract}
The purpose of this research was to find out the correlation linguistic intelligence with Indonesia language knowledge competencies in Elementary School Gugus I Gusti Ngurah Rai Denpasar Barat Grade V academic period 2017/2018. The type of this research was ex post facto. Research populations were all students Grade V in Elementary School Gugus I Gusti Ngurah Rai Denpasar Barat academic period 2017/2018 which has population over 533 students. Sample was determined by proportional technique random sampling with the level of signification $5 \%$ and the number of sample gained from the populations were 218 students. The data retrieved from the recording of language knowledge competencies document Indonesia and linguistic intelligence from essays test by respondents. As the test persyarat is a test of normality distribution data. And the next is testing a hypothesis using correlation analysis product moment. Based on the analysis results we found that $r_{x y c o u n t}=0.448$. At a level of signification $5 \%$ with $n=218$, obtained $r_{x y t a b l e}=0.138$. Because $r_{x y c o u n t}>r_{\text {xytable }}=0.448>0.138$ it means that $H_{0}$ that said there is no significant correlation between linguistic intelligence with Indonesia language knowledge competencies in Elementary School Gugus I Gusti Ngurah Rai Denpasar Barat Grade V academic period 2017/2018 was rejected and $H_{a}$ was accepted. The conclusion was there is correlation between linguistic intelligence with Indonesia language knowledge competencies in Elementary School Gugus I Gusti Ngurah Rai Denpasar Barat Grade V academic period 2017/2018, with positive correlation line, which means the higher the linguistic intelligence will increase with Indonesia language knowledge competencies of students
\end{abstract}

Keywords : linguistic intelligence, Indonesia language knowledge competencies 


\section{Pendahuluan}

Pendidikan merupakan pondasi dasar setiap negara untuk memajukan dan mencerdaskan bangsanya. Pendidikan memiliki peran penting didalam kemajuan sebuah negara dengan memiliki generasi penerus bangsa yang cerdas. Dalam rangka mencerdaskan kehidupan bangsa, maka peningkatan mutu pendidikan merupakan suatu hal yang penting bagi pembangunan dan perkembangan sebuah bangsa. Hamalik (2005:2) menyebutkan "Pendidikan adalah usaha sadar untuk menyiapkan peserta didik melalui kegiatan bimbingan, pengajaran, dan/atau latihan bagi peranannya di masa yang akan datang". Pendidikan pun sangat erat kaitannya dengan kurikulum. Kurikulum merupakan perangkat mata pelajaran dan program pendidikan yang diberikan oleh lembaga penyelenggara pendidikan yang berisi tentang rancangan pembelajaran yang akan diberikan kepada peserta pembelajaran dalam satu periode jenjang pendidikan. Kurikulum yang sedang diterapkan saat ini adalah kurikulum 2013 Di provinsi Bali khususnya kota Denpasar merupakan salah satu daerah yang sudah menerapkan Kurikulum 2013 secara serentak, hampir seluruh sekolah SD, SMP dan SMA/K sederajat menerapkan Kurikulum 2013. Sementara di daerah lainnya di provinsi Bali, Kurikulum 2013 masih minim diterapkan karena kurikulum 2006 (KTSP) masih diterapkan kecuali kota Denpasar. Kurikulum 2013 merupakan aktualisasi kurikulum dalam pembelajaran dan pembentukkan kompetensi serta karakter siswa. Hal tersebut menuntut keaktifan guru dalam menciptakan dan menumbuhkan berbagai kegiatan sesuai dengan rencana yang telah diprogramkan pada RPP (Rencana Pelaksanaan Pembelajaran).

Penerapan Kurikulum 2013 untuk semua satuan pendidikan dasar dan menengah, merupakan salah satu langkah sentral dan strategis untuk menciptakan kerangka penguatan karakter menuju bangsa Indonesia yang madani. Kurikulum 2013 didesain berdasarkan pada budaya dan karakter budaya Indonesia, berbasis peradaban dan berbasis pada kompetensi. Dengan demikian, Kurikulum 2013 diyakini mampu mendorong terwujudnya manusia Indonesia yang bermartabat, beradab, berbudaya, berkarakter, beriman, bertaqwa kepada Tuhan Yang Maha Esa, berakhlak mulia, sehat, berilmu, cakap, kreatif, mandiri dan menjadi warga negara yang demokratis, bertanggung jawab, serta mampu menghadapi berbagai rintangan yang muncul di masa depan. Pada Kurikulum 2013 siswa melaksanakan pembelajaran melalui kegiatan $5 \mathrm{M}$ yang mencakup mengamati, menanya, mengumpulkan informasi atau mencoba, menalar atau mengasosiasi, dan mengomunikasikan.

Asril (2015:2) menyebutkan dalam bukunya bahwa,

kurikulum 2013 juga menuntut guru untuk memiliki 7 keterampilan diantaranya (1) Keterampilan Penugasan; (2) Keterampilan Penguatan; (3) Keterampilan Pendampingan; (4) Keterampilan Menanya; (5) Keterampilan Literasi; (6) Keterampilan IPTEK (Ilmu Pengetahuan dan Teknologi); (7) Keterampilan Membangun Karakter; dan (8) Keterampilan Evaluasi. Guru juga harus menyadari bahwa dalam proses transformasi edukatif perlu adanya komunikasi antara guru dengan peserta didik yang mengandung unsur-unsur pedagogis, psikologis, dan didaktis secara bersamaan.

Menurut pendapat tersebut dalam melaksanakan pembelajaran guru bisa dihadapkan pada situasi dan kondisi yang tidak terduga. Untuk mengatasi hal ini guru harus memiliki keterampilan dan mampu untuk menciptakan suatu variasi pembelajaran yang dapat dilakukan agar pembelajaran tetap dapat terlaksana.

Mulyasa (2011:78) mengemukakan bahwa,

penggunaan variasi dalam mengajar akan meningkatkan perhatian peserta didik terhadap materi, memberikan kesempatan bagi perkembangan bakat peserta didik, memupuk perilaku positif peserta didik terhadap pembelajaran, dan memberikan kesempatan kepada peserta didik untuk belajar sesuai dengan tingkat perkembangan dan kemampuannya.

Pembelajaran yang efektif, bervariasi dan bermakna memungkinkan siswa akan lebih aktif dalam proses pembelajaran. Pembelajaran yang bervariasi akan mengundang rasa ingin tahu siswa tentang materi yang akan dibahas saat pembelajaran. 
Bentuk nyata yang dapat dilihat dan dirasakan dari kegiatan pembelajaran ini adalah pengusaan kompetensi terhadap materi yang diajarkan. Finch \& Crunkilton (Mulyasa, 2002:38) mengartikan "kompetensi sebagai penguasaan terhadap suatu tugas, keterampilan, sikap dan apresiasi yang diperlukan untuk menunjang keberhasilan". Kompetensi dikatakan sebagai kemampuan untuk mencapai standar lulusan yang harus dimiliki siswa. Dengan demikian, maka kompetensi berkaitan dengan hasil belajar. "Hasil belajar yaitu perubahan-perubahan yang terjadi pada diri siswa, baik yang menyangkut aspek kognitif, afektif dan psikomotor sebagai hasil dari kegiatan belajar" (Susanto, 2013:5).

Kemampuan siswa dalam mengikuti dan memahami suatu pembelajaran tidak lepas dari kemampuan berbahasa siswa karena bahasa merupakan bentuk utama dalam mengekspresikan pengetahuan dan pikiran ketika individu melakukan interaksi dengan individu lainnya. Kemampuan berbahasa siswa merupakan salah satu hal yang sangat penting karena dengan berbahasa tersebut siswa dapat berkomunikasi dengan teman ataupun orang terdekatnya. Kemampuan berbahasa merupakan salah satu kecerdasan yang sudah dimiliki seseorang sedari lahir. Perkembangan kecerdasan linguistik siswa diajarkan agar siswa memiliki pemahaman dan komunikasi baik secara lisan, tulisan dan kata-kata yang diperlukan dalam melakukan komunikasi dengan individu lain secara verbal atau non verbal.

Kecerdasan linguistik dapat terlihat dari kemampuan siswa dalam menyampaikan argumentasi didalam pembelajaran atau kebiasaan gemar membaca dan dapat memahami makna bahasa tulisan dengan jelas.

Dalam penguasaan suatu bahasa baru, siswa ini umumnya memiliki kemampuan yang lebih tinggi dibandingkan dengan siswa lainnya. Pernyataan tersebut dapat menunjukkan bahwa kecerdasan linguistik merupakan kecerdasan yang dapat menggali potensi siswa baik melalui aspek kognitif, afektif dan psikomotor. Dalam menggali potensi siswa dalam berbahasa dapat melalui penguasaan kompetensi bahasa Indonesia. Bahasa Indonesia merupakan salah satu muatan materi pelajaran wajib di sekolah dasar yang dapat mengembangkan kecerdasan linguistik anak baik secara verbal atau pun non verbal. Bahasa Indonesia di sekolah dasar memiliki 4 aspek penting dalam membelajarkan siswa yaitu mendengarkan, berbicara, membaca dan menulis. Ke empat aspek tersebut akan membantu siswa untuk mengembangkan potensinya.

Kecerdasan linguistik berhubungan dengan perkembangan bahasa anak. Kompetensi yang harus dimiliki oleh siswa sekolah dasar yaitu keterampilan mendengarkan, berbicara, membaca, menulis serta kemampuan dalam berkomunikasi secara jelas dan santun. Kompetensi-kompetensi itu berkaitan dengan kecerdasan siswa dalam berbahasa yang biasa disebut dengan kecerdasan linguistik. Kecerdasan linguistik dalam pembelajaran sangat penting dan harus diterapkan karena dalam proses pembelajaran diperlukan 4 kompetensi bahasa Indonesia dan penggunaan kecerdasan linguistik yaitu mendengarkan, berbicara, membaca dan menulis dalam menerima materi. Dalam mengembangkan kecerdasan linguistik anak di sekolah dasar, guru tentunya harus memiliki strategi yang tepat dalam melaksanakan pembelajaran dikelas terutama dalam mata pelajaran bahasa Indonesia. Bahasa Indonesia memiliki beberapa aspek yang patut dikuasai oleh siswa sekolah dasar yaitu mendengarkan, berbicara, membaca dan menulis. Kecerdasan linguistik yang dimiliki oleh siswa jika dikembangkan dengan tepat oleh guru dan siswa itu sendiri maka penguasaan kompetensi terutama pada penguasaan kompetensi bahasa Indonesia siswa akan tercapai optimal dan sebaliknya jika siswa memiliki kecerdasan linguistik namun tidak dikembangkan oleh guru dan siswa sendiri maka penguasaan kompetensi pengetahuan bahasa Indonesia siswa akan tercapai kurang optimal.

Dalam proses mengembangkan penguasaan kompetensi pengetahuan bahasa Indonesia, diperlukan ke empat aspek penting tersebut yang dapat melatih perkembangan kecerdasan linguistik siswa. Namun pada kenyataannya, minat siswa terhadap ilmu pengetahuan bahasa Indonesia masih tergolong rendah dan menyebabkan siswa beranggapan bahwa bahasa Indonesia merupakan mata pelajaran yang mudah. Berdasarkan pada observasi yang telah dilaksanakan pada bulan Januari 2018, bahwa ada siswa yang ditandai memiliki kecerdasan linguistik mampu memiliki nilai kompetensi 
pengetahuan bahasa Indonesia yang baik. Ada siswa yang tidak ditandai memiliki kecerdasan liguistik namun siswa ini mampu memiliki nilai kompetensi pengetahuan bahasa Indonesia yang baik pula. Ada pula siswa yang ditandai memiliki kecerdasan linguistik namun siswa ini tidak mampu memiliki nilai kompetensi pengetahuan bahasa Indonesia yang baik, sehingga guru belum mengoptimalkan kecerdasan linguistik yang dimiliki oleh siswa. Penelitian dilakukan untuk mengetahui korelasi antara kecerdasan linguistik dengan kompetensi pengetahuan bahasa Indonesia, penelitian tersebut akan dilaksanakan dengan judul "Korelasi Antara Kecerdasan Linguistik dengan Kompetensi Pengetahuan Bahasa Indonesia Siswa Kelas V SD Gugus I Gusti Ngurah Rai Denpasar Barat Tahun Pelajaran 2017/2018."

\section{Metode}

Penelitian yang dilakukan di SD Gugus I Gusti Ngurah Rai Denpasar Barat menggunakan rancangan penelitian ex post facto.

Penelitian ini pada dasarnya bertujuan untuk mengetahui korelasi antara kecerdasan linguistik dengan penguasaan kompetensi pengetahuan bahasa Indonesia, dengan tidak memanipulasi variabel bebas atau menggali fakta yang sudah terjadi sebelumnya sehingga penelitian ini tergolong penelitian ex post facto korelasional. Variabel bebas pada penelitian ini adalah kecerdasan linguistik sedangkan variabel terikatnya adalah kompetensi pengetahuan bahasa Indonesia pada siswa SD kelas V. Populasi dalam penelitian ini adalah siswa kelas V SD Gugus I Gusti Ngurah Rai Denpasar Barat tahun pelajaran 2017/2018 yang berjumlah 533 siswa.

Berdasarkan tabel Issac and Michael, jumlah populasi yan terdapat di Gugus I Gusti Ngurah Rai adalah 533 siswa dan jumlah sampel yang diambil berdasarkan tingkat kesalahan $5 \%$ berjumlah 218 orang siswa. Pengambilan sampel dalam penelitian ini menggunakan teknik proporsional random sampling yang artinya teknik pengambilan sampel secara acak dengan memperhatikan jumlah siswa dari masing-masing kelas sesuai dengan proporsi yang terdapat didalam populasi tersebut.

Metode pengumpulan data dalam penelitian ini meliputi data tentang penguasaan kompetensi pengetahuan bahasa Indonesia dan kecerdasan linguistik. Metode pengumpulan data dalam penelitian yaitu menggunakan metode tes dan non tes (pencatatan dokumen). Kompetensi pengetahuan bahasa Indonesia siswa diperoleh melalui pencatatan dokumen, sedangkan untuk mengetahui tingkat kecerdasan linguistik siswa maka digunakan metode tes yakni tes uraian (essay test).

Instrumen yang digunakan untuk mengukur tingkat kecerdasan linguistik siswa adalah tes kecerdasan linguistik. Tes yang digunakan adalah tes yang sudah disesuaikan dengan indikator kecerdasan linguistik yang memiliki aspek pengetahuan bahasa Indonesia yaitu membaca dan menulis.

Indikator kecerdasan linguistik terdiri dari 2 aspek yaitu membaca dan menulis. membaca memiliki dua indikator yaitu 1) memahami isi bacaan; dan 2) menarik simpulan dari isi bacaan, sedangkan menulis memiliki tiga indikator yaitu 1) menyusun kalimat SPOK dengan tepat; 2) menyusun kalimat dengan menggunakan kata depan (Ke, Di); dan 3) menentukan kata baku dan tidak baku. Sedangkan untuk megukur kompetensi pengetahuan bahasa Indonesia siswa digunakan nilai akhir semester 1 siswa kelas V. Instrumen ted kecerdasan linguistik dan nilai akhir kompetensi pengetahuan bahasa Indonesia tersebut sebagai alat ukur untuk mengetaui sejauh mana kecerdasan linguistik dan kompetensi pengetahuan bahasa Indoenesia yang dimiliki oleh siswa kelas V SD Gugus I Gusti Ngurah Rai Denpasar Barat tahun pelajaran 2017/2018. Jumlah masing-masing butir tes kecerdasan linguistik yaitu 10 butir tes. Pengujian instrumen dalam penelitian ini menggunakan validitas empirik, validitas isi, validitas konstrak dan uji reliabilitas. Cara pemberian skor pada tes kecerdasan linguistik menggunakan kunci jawaban dan berdasarkan pada rubrik penilaian.

Pencatatan dokumen yang digunakan untuk pengumpulan data absensi dan nilai kompetensi pengetahuan bahasa Indonesia siswa kelas V SD Gugus I Gusti Ngurah Rai Denpasar Barat Tahun Pelajaran 2017/2018. 
Analisis dalam penelitian ini menggunakan analisis statistik inferensial. Teknik analisis data yang digunakan teknik korelasi product moment yang digunakan unuk mencari hubungan dua variabel yaitu variabel bebas dan variabel terikat dengan menggunakan data interval atau ratio. Untuk memenuhi persyaratan uji hipotesis maka diperlukan uji persyaratan analisis yaitu uji normalitas dan uji hipotesis statistik.

Uji normalitas digunakan untuk menguji apakah data variabel bebas dan variabel terikat berdistribusi normal atau tidak, dengan cara menggunakan rumus chi-kuadrat dengan kriteria yang digunakan adalah dengan membandingkan nilai $\mathrm{X}^{2}$ tabel dengan $\mathrm{X}^{2}$ hitung pada taraf signifikan 5\% dengan ketentuan $\mathrm{X}^{2}{ }_{\text {hitung }}<\mathrm{X}^{2}$ tabel maka data berdistribusi normal.

Uji hipotesis statistik menggunakan korelasi product moment dengan mengetes antara variabel bebas $(\mathrm{X})$ dan variabel terikat $(\mathrm{Y})$. Hipotesis yang diuji dalam penelitian ini adalah $\mathrm{H}_{\mathrm{o}}$ yang berbunyi tidak terdapat korelasi yang signifikan antara kecerdasan linguistik dengan kompetensi pengetahuan bahasa Indonesia siswa kelas V SD Gugus I Gusti Ngurah Rai Denpasar Barat tahun pelajaran 2017/2018. Kriteria yang digunakan dalam pengujian korelasi product moment ini yaitu dengan menggunakan taraf signifikan 5\%. Adapun ketentuan yang diuji dalam penelitian ini jika $r_{x y}$ hitung $>r_{x y t a b e l}$ maka $H_{0}$ ditolak berarti terdapat korelasi antara kecerdasan linguistik $(X)$ dengan kompetensi pengetahuan bahasa Indonesia (Y) siswa kelas V SD Gugus I Gusti Ngurah Rai Denpasar Barat tahun pelajaran 2017/2018. sebaliknya jika $r_{x y}$ hitung $<r_{x y}$ tabel maka $H_{0}$ diterima berarti tidak terdapat korelasi kecerdasan linguistik (X) dengan kompetensi pengetahuan bahasa Indonesia (Y) siswa kelas V SD Gugus I Gusti Ngurah Rai Denpasar Barat tahun pelajaran 2017/2018.

\section{Hasil dan Pembahasan}

\section{Deskripsi Data Kecerdasan Linguistik}

Data mengenai kecerdasan linguistik siswa kelas V SD Gugus I Gusti Ngurah Rai Denpasar Barat tahun pelajaran 2017/2018 diperoleh melalui penyebaran tes kecerdasan linguistik. Sampel yang dibagikan tes kecerdasan liguistik berjumlah 218 responden dengan 10 butir tes uraian (essay test). Data nilai tes kecerdasan linguistik dapat dilihat sebagai berikut:

Tabel 1. Data Nilai tes kecerdasan linguistik siswa kelas V SD Gugus I Gusti Ngurah Rai Denpasar Barat tahun pelajaran 2017/2018

\begin{tabular}{|c|c|}
\hline Data Statistik & Nilai \\
\hline Mean & 75,30 \\
\hline Nilai Minimum & 56 \\
\hline $\begin{array}{c}\text { Nilai } \\
\text { Maksimum }\end{array}$ & 98 \\
\hline
\end{tabular}

Berdasarkan data nilai tes kecerdasan linguistik siswa kelas V SD Gugus I Gusti Ngurah Rai Denpasar Barat Tahun Pelajaran 2017/2018 mendapatkan nilai rerata 75,30 . Nilai tes kecerdasan linguistik siswa yang tertinggi adalah 98 dan yang terendah adalah 56 .

Dari data di atas dapat juga dilihat dalam bentuk grafik, sehingga dapat dilihat sebagai berikut : 
Gambar 1. Histogram Data Kecerdasan

Linguistik

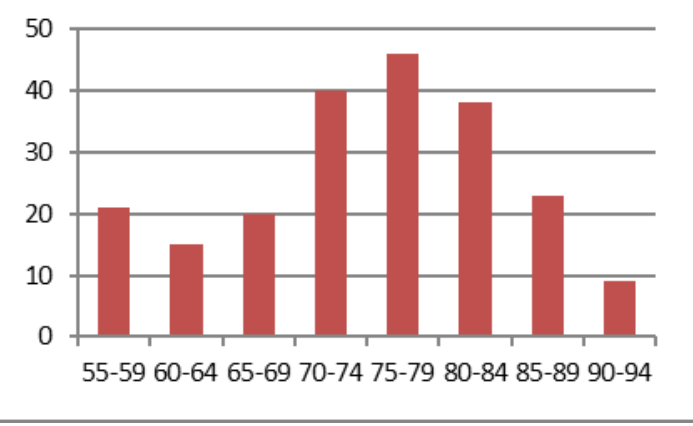

Berdasarkan diagram tentang data kecerdasan linguistik dapat diketahui bahwa frekuensi nilai terbanyak terdapat pada kelas interval ke-5, selanjutnya dapat dilihat data berikut ini tentang tingkat kategori kecerdasan linguistik siswa SD di Gugus I Gusti Ngurah Rai, Denpasar Barat.

Tabel 2. Pedoman Konversi PAP Skala Lima tentang Kecerdasan Linguistik (Sumber: Agung,2014)

\begin{tabular}{|c|c|}
\hline $\begin{array}{c}\text { Persentase Kecerdasan } \\
\text { Linguistik }\end{array}$ & $\begin{array}{c}\text { Kriteria Kecerdasan } \\
\text { Linguistik }\end{array}$ \\
\hline $90-100$ & Sangat Baik \\
\hline $80-89$ & Baik \\
\hline $65-79$ & Cukup Baik \\
\hline $55-64$ & Kurang Baik \\
\hline $0-54$ & Sangat Kurang Baik \\
\hline
\end{tabular}

Berdasarkan tentang kategori kecerdasan linguistik siswa diatas serta hasil dari analisis data, bahwa rerata dari kecerdasan linguistik siswa adalah 75,30 dan nilai tersebut berada pada nilai PAP rentang $65-79$. Berdasarkan hal tersebut, dapat disimpulkan bahwa kecerdasan linguistik siswa kelas V SD di Gugus I Gusti Ngurah Rai, Denpasar Barat tergolong cukup baik.

\section{Deskripsi Data Kompetensi Pengetahuan Bahasa Indonesia}

Data tentang kompetensi pengetahuan bahasa Indoensia siswa kelas V SD Gugus I Gusti Ngurah Rai Denpasar Barat tahun pelajaran 2017/2018 diperoleh melalui metode pencatatan dokumen yaitu mencatat nilai akhir semester 1 siswa kelas V SD Gugus I Gusti Ngurah Rai Denpasar Barat tahun pelajaran 2017/2018. Sampel yang dicatat nilai akhir semesternya berjumlah 218 orang responden. data tentang nilai akhir semester 1 siswa kelas V SD Gugus I Gusti Ngurah Rai Denpasar Barat tahun pelajaran 2017/2018 dapat dilihat sebagai berikut:

Tabel 3. Data Hasil Nilai Kuesioner Interaksi Sosial di Kelas Siswa Kelas IV SD Gugus VII Kuta Selatan

\begin{tabular}{cc}
\hline Data Statistik & Nilai \\
\hline Mean & 79,43 \\
\hline Skor Minimum & 62 \\
\hline Skor Maksimum & 95
\end{tabular}

Berdasarkan data nilai akhir kompetensi pengetahuan bahasa Indonesia siswa kelas V SD Gugus I Gusti Ngurah Rai Denpasar Barat tahun pelajaran 2017/2018 mendapatkan 
rerata nilai 79,43 . Nilai kompetensi pengetahuan bahasa Indonesia tertinggi adalah 95 dan yang terendah adalah 62.

Dari data di atas dapat juga dilihat dalam bentuk grafik, sehingga dapat dilihat sebagai berikut :

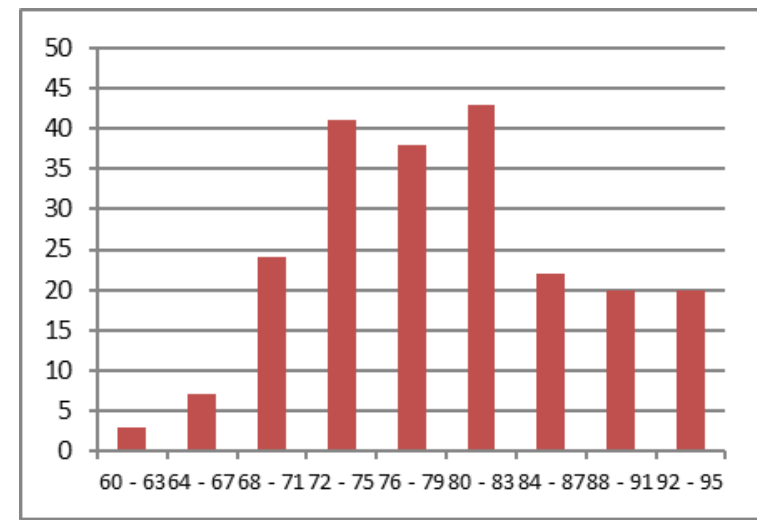

Gambar 2. Histogram Data kompetensi pengetahuan bahasa Indonesia

Berdasarkan diagram tentang data kompetensi pengetahuan bahasa Indonesia dapat diketahui bahwa frekuensi nilai terbanyak terdapat pada interval ke-6 dengan rentang nilai 80 - 83. Selanjutnya dapat dilihat data berikut ini tentang tingkat kategori kompetensi pengetahuan bahasa Indonesia siswa kelas V SD di Gugus I Gusti Ngurah Rai, Denpasar Barat.

Tabel 4. Pedoman Konversi PAP Skala Lima tentang Kompetensi Pengetahuan Bahasa Indonesia

(Sumber: Agung,2014)

\begin{tabular}{cc}
\hline $\begin{array}{c}\text { Persentase Kompetensi } \\
\text { Pengetahuan Bahasa Indonesia }\end{array}$ & $\begin{array}{c}\text { Kriteria Kompetensi } \\
\text { Pengetahuan Bahasa Indonesia }\end{array}$ \\
\hline $90-100$ & Sangat Baik \\
\hline $80-89$ & Baik \\
\hline $65-79$ & Cukup Baik \\
\hline $55-64$ & Kurang Baik \\
\hline $0-54$ & Sangat Kurang Baik
\end{tabular}

Berdasarkan kategori tentang kategori tingkat kompetensi pengetahuan bahasa Indonesia siswa serta hasil dari analisis data, bahwa rerata dari kompetensi pengetahuan bahasa Indonesia siswa adalah 79,43 dan nilai tersebut berada pada nilai PAP rentang 65 79. Maka dapat disimpulkan bahwa kompetensi pengetahuan bahasa Indonesia siswa kelas V SD di Gugus I Gusti Ngurah Rai, Denpasar Barat tergolong cukup baik.

\section{Uji Prasyarat Analisis}

Uji normalitas kecerdasan linguistik (X) dan kompetensi pengetahuan bahasa Indonesia $(Y)$ menggunakan teknik uji Chi-Kuadrat $\left(x^{2}\right)$. Nilai dari variabel $X$ dan $Y$ dapat dikatakan berdistribusi normal apabila $x^{2}$ hitung $<\mathrm{x}^{2}$ tabel.

Hasil uji normalitas kecerdasan linguistik $(X)$ yaitu $X^{2}{ }_{\text {hitung }}=10,4$. Berdasarkan analisis maka diperoleh $\mathrm{x}^{2}$ hitung $=10,4$ dan menggunakan taraf signifikansi $5 \%$ dengan menggunakan derajat kebebasan 5, maka diperoleh $x^{2}$ tabel $=11,07$. Hal ini berati $x^{2}$ nitung $10,4<x^{2}$ tabel 11,07 maka dapat dinyatakan sebaran data berdistribusi normal. Sedangkan hasil uji normalitas kompetensi pengetahuan bahasa Indonesia $(\mathrm{Y})$ yaitu $\mathrm{x}^{2}$ hitung $=9,18$. Berdasarkan analisis maka diperoleh $\mathrm{x}^{2}$ hitung $=9,18$ dan menggunakan taraf signifikansi $5 \%$ dengan menggunakan derajat kebebasan 5, maka diperoleh $x_{\text {tabel }}^{2}=11,07$. Hal ini berati $x^{2}$ nitung $9,18<x^{2}{ }_{\text {tabel }} 11,07$ maka dapat dinyatakan sebaran data berdistribusi normal. Hasil tersebut membuktikan bahwa data kedua variabel bebas dan terikat bersifat normal. 


\section{Pengujian Hipotesis}

Setelah dilakukan uji prasyarat dan diketahui data berdistribusi normal, dilanjutkan dengan uji hipotesis guna mengetahui adanya korelasi antar variabel. Uji hipotesis yang dilakukan adalah uji hipotesis dengan menggunakan teknik analisis product moment (variabel $\mathrm{X}$ dengan variabel $\mathrm{Y}$ ), maka untuk tujuan analisis data dirumuskan dalam hipotesis nol $\left(\mathrm{H}_{0}\right)$. Hipotesis yang dirumuskan yaitu $\mathrm{H}_{0}$ : Tidak terdapat korelasi yang signifikan antara kecerdasan linguistik dengan kompetensi pengetahuan bahasa Indonesia siswa kelas V SD Gugus I Gusti Ngurah Rai Denpasar Barat tahun pelajaran 2017/2018.

Berdasarkan tabel penolong untuk mencari nilai $r$ dengan menggunakan rumus product moment dan dibantu menggunakan Microsoft excel 2010. Pengujian koefisien korelasi dengan rumus product moment diperoleh hasil $r_{x y}=0,448$. Untuk uji koefisien korelasi, digunakan nilai tabel product moment $(r)$ untuk $n=218$, pada taraf signifikansi $5 \%$ diperoleh $r_{\text {tabel }}$ sebesar 0,138. Maka dapat dinyatakan $r_{\text {hitung }}>r_{\text {tabel. }}$. Ini menyatakan bahwa nilai $r_{\text {hitung }}$ signifikan dengan nilai 0,448 , sehingga $\mathrm{H}_{0}$ yang berbunyi tidak terdapat korelasi yang signifikan antara kecerdasan linguistik dengan kompetensi pengetahuan bahasa Indonesia kelas V SD gugus I Gusti Ngurah Rai Denpasar Barat tahun pelajaran 2017/2018 ditolak, dan $\mathrm{H}_{\mathrm{a}}$ diterima. Hal ini menunjukan bahwa terdapat korelasi yang signifikan antara kecerdasan linguistik dengan kompetensi pengetahuan bahasa Indonesia. Sedangkan arah korelasi adalah positif, berarti semakin tinggi kecerdasan linguistik yang dimiliki siswa maka kompetensi pengetahuan bahasa Indonesia siswa semakin meningkat.

\section{PEMBAHASAN}

Berdasarkan pada hasil penelitian dan analisis data yang dilakukan, diperoleh hasil $r_{x y}=0,448$ dan nilai tabel product moment $(r)$ untuk $n=218$, pada taraf signifikansi $5 \%$ diperoleh $r_{\text {tabel }}$ sebesar 0,138 dan hasil analisis yang diperoleh yaitu $r_{\text {hitung }}>r_{\text {tabel }}$, sehingga $\mathrm{H}_{0}$ yang berbunyi tidak terdapat korelasi yang signifikan antara kecerdasan linguistik dengan kompetensi pengetahuan bahasa Indonesia kelas V SD gugus I Gusti Ngurah Rai Denpasar Barat tahun pelajaran 2017/2018 ditolak dan $\mathrm{H}_{\mathrm{a}}$ diterima. Berdasarkan uraian tersebut maka dikemukakan interpretasi, yang menyatakan bahwa rata-rata siswa yang memiliki kecerdasan linguistik akan memiliki nilai kompetensi pengetahuan bahasa Indonesia yang tinggi dalam mengikuti pembelajaran.

Berdasarkan uraian tersebut, siswa yang memiliki kecerdasan linguistik akan memiliki potensi yang baik dalam pembelajaran bahasa Indonesia dibeberapa indikator seperti membaca dan menulis sehingga secara tidak langsung potensi yang dimiliki siswa dalam bidang kebahasaan akan berkembang. Hal ini sesuai dengan pendapat Umareani (Tahun 2014, Volume: 2) yang yang menyatakan bahwa,

kecerdasan linguistik menekankan empat keterampilan berbahasa yaitu mendengarkan, berbicara, membaca dan menulis sehingga dengan mengembangkan kecerdasan linguistik siswa maka siswa akan memiliki potensi yang baik dalam mengembangkan empat aspek berbahasa yaitu mendengarkan, berbicara, membaca dan menulis.

Berdasarkan hasil analisis data yang dilakukan pada penelitian ini diperoleh $r_{\text {hitung }}=$ 0,448 dengan $r_{\text {tabel }}$ pada taraf signifikansi $5 \%$ nilai $r_{\text {tabel }}$ untuk $n=218$ adalah 0,138 . Hal ini menyatakan bahwa $r_{\text {hitung }}>r_{\text {tabel. }}$ Sejalan dengan penelitian Karter,dkk (Tahun 2014, Volume: 2) yang menyatakan $r_{\text {hitung }}<r_{\text {tabel }}(0,062<0,456)$ yang artinya $H_{0}$ yang menyatakan tidak ada hubungan komunikasi orang tua dan guru dengan prestasi belajar siswa diterima, begitu pula sebaliknya yaitu $\mathrm{Ha}$ yang diajukan ditolak. Berdasarkan pemaparan tersebut, maka dapat disimpulkan bahwa semakin tinggi kecerdasan linguistik yang dimiliki oleh siswa maka siswa tesebut memiliki nilai kompetensi pengetahuan bahasa Indonesia yang tinggi. Kecerdasan linguistik yang dimiliki oleh siswa berhubungan dengan perkembangan bahasa yang didapatkan didalam mata pelajaran bahasa Indonesia. Pengetahuan kompetensi bahasa Indonesia yang harus dikembangkan oleh siswa sekolah dasar yaitu keterampilan mendengarkan, berbicara, membaca, menulis serta kemampuan dalam berkomunikasi 
secara jelas dan santun. Dalam menerima materi pembelajaran, siswa harus memiliki kemampuan untuk berkomunikasi dan berinteraksi dengan siswa lainnya dan guru. Kemampuan untuk berkomunikasi diperoleh dari kemampuan berbahasa yang baik.

Dalam bahasa Indonesia terdapat 4 kompetensi berbahasa yang berkaitan dengan kecerdasan linguistik siswa yaitu mendengarkan, berbicara, membaca dan menulis. Kecerdasan linguistik dalam pembelajaran sangat penting dan harus diterapkan karena dalam proses pembelajaran mata pelajaran apapun diperlukan 4 kompetensi bahasa Indonesia dan penggunaan kecerdasan linguistik yaitu mendengarkan, berbicara, membaca dan menulis dalam menerima materi. Sehingga jika siswa memiliki kecerdasan linguistik dalam aspek keterampilan mendengarkan, berbicara, membaca, dan menulis yang tinggi maka kompetensi pengetahuan bahasa Indonesia yang dimiliki siswa juga tinggi dan meningkat

\section{Simpulan dan Saran}

Hasil penelitian dalam pembahasan menunjukkan bahwa terdapat korelasi yang signifikan antara kecerdasan linguistik dengan kompetensi pengetahuan bahasa Indonesia siswa kelas V SD Gugus I Gusti Ngurah Rai Denpasar Barat tahun pelajaran 2017/2018. Kategori yang diperoleh adalah termasuk dalam kategori sedang antara kecerdasan linguistik dengan kompetensi pengetahuan bahasa Indonesia. Arah korelasinya adalah positif karena nilai $r$ positif, yang berarti bahwa semakin tinggi kecerdasan linguistik

Berdasarkan hasil analisis dengan menggunakan Microsoft excel 2010 dan menghitung manual diperoleh $r_{\text {hitung }}=0,448$ dengan $r_{\text {tabel }} 0,138$ yang berarti $r_{\text {hitung }}>r_{\text {tabel }}$, sehingga $\mathrm{H}_{0}$ yang berbunyi tidak terdapat korelasi yang signifikan antara kecerdasan linguistik dengan kompetensi pengetahuan bahasa Indonesia siswa kelas V SD Gugus I Gusti Ngurah Rai Denpasar Barat Tahun Pelajaran 2017/2018 ditolak.

Berdasarkan hasil penelitian tersebut, dapat disimpulkan bahwa rata-rata siswa yang tergolong memiliki kecerdasan linguistik akan mampu untuk meningkatkan kompetensi pengetahuan bahasa Indonesia. Dapat diartikan pula bahwa semakin tinggi kecerdasan linguistik yang dimiliki siswa, maka semakin tinggi kompetensi pengetahuan bahasa indonesia sehingga yang dapat dicapai secara optimal oleh siswa. Jadi dapat disimpulkan bahwa terdapat korelasi yang signifikan antara kecerdasan linguistik dengan kompetensi pengetahuan bahasa indonesia dan memiliki arah korelasi positif pada kategori korelasi yang sedang ( $\left.\mathrm{r}_{\text {hitung }}=0,448\right)$.

Adapun saran yang ingin disampaikan sebagai berikut: (1), Kepada guru disarankan lebih mampu untuk meningkatkan kecerdasan linguistik yang dimiliki siswa melalui aktivitasaktivitas belajar di dalam kelas ataupun di luar kelas sehingga tujuan pembelajaran khususnya mata pelajaran bahasa Indonesia dapat tercapai secara optimal; (2) Kepada kepala sekolah hendaknya dapat menggunakan hasil penelitian ini sebagai pendukung sumber belajar guru dalam meningkatkan kualitas pembelajaran dengan mengembangkan kecerdasan linguistik yang dimiliki siswa dalam belajar di sekolah sehingga sekolah dapat menghasilkan siswa yang berkualitas; (3) Kepada peneliti lain disarankan agar hasil penelitian ini dapat digunakan sebagai referensi untuk melaksanakan penelitian selanjutnya dan semoga penelitian ini bermanfaat bagi seluruh elemen masyarakat yang menggunakan penelitian ini.

\section{Daftar Pustaka}

Agung, Gede.2014. Metodelogi Penelitian Pendidikan. Malang: Aditya Media Publising.

Asril, Zainal. 2015. Micro Teaching. Jakarta: PT. Rajagrafindo Persada.

Hamalik, Oemar. 2005. Proses Belajar Mengajar. Jakarta: PT. Bumi Aksara. 
Karter,dkk. 2014. "Hubungan Komunikasi Orang Tua dan Guru dengan Prestasi Belajar Siswa SDN Inpres 2 Lolu." Jurnal media publikasi prodi PGSD. Volume 2, nomor 1. Tersedia pada http://download.portalgaruda.org/ (diakses tanggal 2 Januari 2018)

Mulyasa. 2002. Kurikulum Berbasis Kompetensi. Bandung: PT Remaja Rosdakarya.

Mulyasa. 2011. Menjadi Guru Profesional Menciptakan Pembelajaran Kreatif dan Menyenangkan. Bandung: PT Remaja Rosdakarya.

Susanto, Ahmad. 2013. Teori Belajar dan Pembelajaran di Sekolah Dasar. Jakarta: Prenadamedia Grup.

Umareani, Deshi. 2014. "Hubungan Antara Kecerdasan Lingustik dan Konsep Diri dengan Prestasi Belajar Bahasa Indonesia Siswa Kelas V Gugus Kompyang Sujana tahun pelajaran 2013/2014." Jurnal Mimbar PGSD Universitas Pendidikan Ganesha, Vol 2, No. Tersedia https://ejournal.undiksha.ac.id/index.php/JJPGSD/article/view/3073 (di akses tanggal 2 Januari 2018) 